\title{
Glutamate-Dependent Activation of NF-кB During Mouse Cerebellum Development
}

\author{
Luisa Guerrini, ${ }^{1}$ Angela Molteni, ${ }^{1}$ Thomas Wirth, ${ }^{3}$ Barbara Kistler, ${ }^{3}$ and Francesco Blasi ${ }^{1,2}$ \\ ${ }^{1}$ Department of Genetics and Microbial Biology, University of Milan, 20133 Milan, Italy, ${ }^{2}$ Dipartimento di Biologia e \\ Biotecnologia, San Raffaele Scientific Institute, 20100 Milan, Italy, and 3/nstitute fuer Medinische Strahlenkunde und \\ Zellforschung, 97078 Wurzburg, Germany
}

\begin{abstract}
$\mathrm{NF}-\kappa \mathrm{B}$ and activator protein 1 (AP-1) are dimeric transcription factors involved in transcriptional regulation in many cells, including neurons. We have examined their activity during mouse cerebellum development, a postnatal process starting just after birth and completed by the fourth postnatal (PN) week. The activity of these factors was analyzed by binding of nuclear extracts to a synthetic oligonucleotide representing the $\kappa \mathrm{B}$ site of human immunodeficiency virus or the AP-1 site of the urokinase promoter. NF- $\kappa$ B activity was observed from $7 \mathrm{PN}$, was restricted to the developing cerebellum, and was not observed in the early postnatal neocortex and hippocampus. On the other hand, AP-1 activity was not found in cerebellum but was present in both neocortex and hippocampus. Moreover, a $\kappa \mathrm{B}$-driven transgene was found to be increasingly expressed in the cerebellum from 5 $\mathrm{PN}$ to $10 \mathrm{PN}$ but not in the adult. The regulation of $\mathrm{NF}-\kappa \mathrm{B}$
\end{abstract}

Neuronal differentiation involves migration, directional growth, synaptogenesis, and selective survival. Cells in the CNS acquire distinct fates in response to extrinsic signals that activate repertoires of transcription factors in a region- and cell-specific manner. The number of transcription factors with known temporal patterns of expression in the developing vertebrate nervous system is increasing rapidly (Bang and Goulding, 1996).

The cerebellum provides a unique model for studying CNS development, because the three maturation processes (morphogenetic movements, formation of ganglionic structures, and neuronal layers) are primarily postnatal events that begin just after birth and are completed by the fourth postnatal (PN) week (Ramon y Cayal, 1889; Altman, 1982). Although the steps of these processes are well known (Hatten and Heintz, 1995), the genes involved in these sequential events are only now beginning to be identified (Kuhar et al., 1993).

The NF- $\kappa \mathrm{B}$ family of transcription factors is composed of five members in vertebrates (RelA, NFKB1, NFKB2, c-Rel, and RelB), sharing a 300 amino acid Rel homology domain and forming heterodimers and homodimers (Grilli et al., 1993). $\mathrm{NF}-\kappa \mathrm{B}$ activity is regulated by specific inhibitors $(\mathrm{I} \kappa \mathrm{Bs})$ that maintain the factor in a cytoplasmic, inactive form (Verma et al.,

Received March 24, 1997; revised May 16, 1997; accepted May 30, 1997.

This work was supported by grants from the Italian Ministry of Health (AIDS fund) and Associazione Italiana Ricerche sul Cancro and European Community. We are grateful to Dr. Nancy Rice for the generous gift of antibodies and Dr. Marco de Curtis for critical reading of this manuscript.

Correspondence should be addressed to Luisa Guerrini, Department of Genetics and Microbial Biology, University of Milan, Via Celoria 26, 20133 Milan, Italy.

Copyright (C) 1997 Society for Neuroscience $0270-6474 / 97 / 176057-07 \$ 05.00 / 0$ activation in mouse cerebellum was analyzed by intraperitoneal injection of glutamate receptor antagonists to 9 PN mice, which abolished NF- $\kappa$ B-binding activity, suggesting an endogenous loop of glutamate receptor activation. Glutamate receptor agonists, on the other hand, induced $\mathrm{NF}-\kappa \mathrm{B}$ nuclear translocation in the cerebellum of $5 \mathrm{PN}$ mice, which is a stage in which NF- $\kappa \mathrm{B}$ is not yet endogenously activated. This effect was specific for NF- $\kappa$ B and not observed for AP-1. In adult mice, NF- $\kappa \mathrm{B}$ activity was absent in the cerebellum and was not induced by intraperitoneal injection of glutamate receptor agonists. These data show that NF- $\kappa \mathrm{B}$ is specifically activated during cerebellum development and indicate an important role of glutamate receptors in this process.

Key words: NF-кB; cerebellum; development; HIV; glutamate; transcription

1995). Several inducers cause dissociation and degradation of $\mathrm{I} \kappa \mathrm{Bs}$ and promote activation of $\mathrm{NF}-\kappa \mathrm{B}$ with rapid translocation into the nucleus, where it directly regulates gene expression. Although NF- $\kappa \mathrm{B}$ factors are widely expressed in almost all cell types analyzed thus far, NF- $\kappa \mathrm{B}$ has been reported to be constitutively activated only in mature B cells (Miyamoto et al., 1994) and in some regions of the adult mouse brain (Schmidt-Ullrich et al., 1996).

Recently we showed that the RelA subunit of NF- $\kappa \mathrm{B}$ was present in several areas of brain, including cerebellum, and that its activation state changed in cerebellar neuronal cultures, reflecting different stages of development. In cerebellar granule cell cultures derived from 4- to 7-d-old PN mice, RelA was retained in the cytoplasm; however, nuclear translocation could be induced by treatment of the cultures with the neurotransmitter glutamate. Nuclear RelA was capable of DNA binding, and its activity could be followed by electrophoretic mobility shift assays (EMSAs). Pretreatment of the cultures with EGTA blocked glutamate activation of $\mathrm{NF}-\kappa \mathrm{B}$, suggesting that $\mathrm{Ca}^{2+}$ influx was required for $\mathrm{NF}-\kappa \mathrm{B}$ activation. In cultures derived from older mice (10 PN) a nuclear DNA-binding NF- $\kappa \mathrm{B}$ was observed (Guerrini et al., 1995). Thus activation of NF- $\kappa \mathrm{B}$ might be connected to cerebellar development.

We now report that, during mouse cerebellum development,

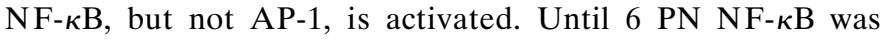
retained in the cell cytoplasm in an inducible state. From 7 PN on, NF- $\kappa \mathrm{B}$ was constitutively activated in the cerebellum. Before $7 \mathrm{PN}$, nuclear translocation of NF- $\kappa \mathrm{B}$ could be obtained using intraperitoneal administration of neurotransmitters; in- 
A

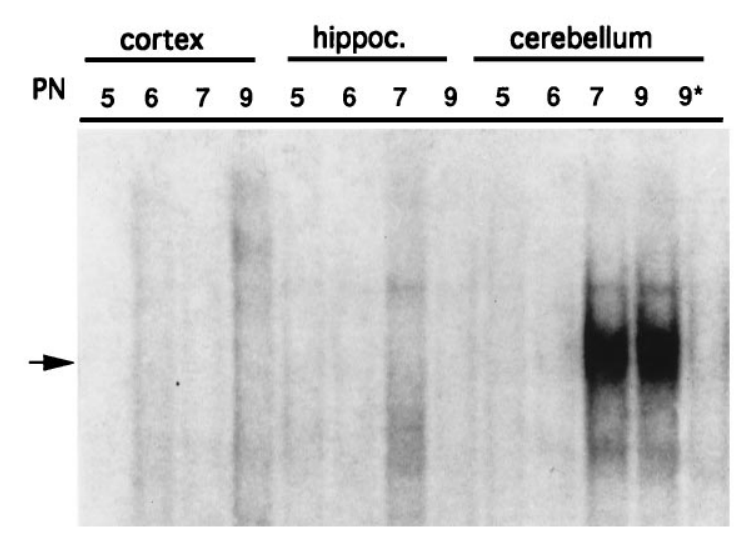

B

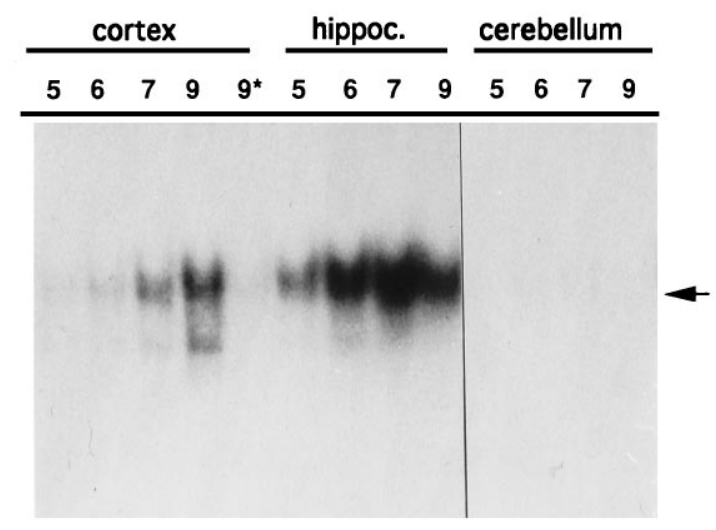

Figure 1. NF- $\kappa \mathrm{B}$ is developmentally activated in the cerebellum. Nuclear extracts from neocortex (cortex), hippocampus (hippoc.), and cerebellum from 5-9 PN mouse pups were used in EMSAs with HIV- $\kappa \mathrm{B}$ and AP-1 oligonucleotides as probes. $A$, NF- $\kappa \mathrm{B}-$ binding activity is not detected in neocortex and hippocampus extracts (5-9 PN); in the cerebellum, NF- $\kappa$ B is not present at 5 and 6 PN but can be detected at 7 and 9 PN. DNA-binding specificity is shown with 9 PN extracts by the competition with a 50 -fold excess of unlabeled oligonucleotide $\left(9^{*}\right)$. The arrow identifies the NF- $\kappa$ B complex. B, AP-1 activity is absent in the neocortex at 5 PN but is present thereafter (6-9 PN). DNA-binding specificity is shown by the competition with a 50-fold excess of unlabeled AP-1 oligonucleotide (9*). In the hippocampus AP-1 is expressed at all stages examined (5-9 PN) but is completely absent in the cerebellum (5-9 PN). The arrow identifies the AP-1 complex.

traperitoneal injection of the glutamate receptor agonists NMDA and trans-methyl-D-aspartic acid (trans-ACPD) resulted in activation of $\mathrm{NF}-\kappa \mathrm{B}$ in cerebella of $5 \mathrm{PN}$ pups. Intraperitoneal injections to $9 \mathrm{PN}$ mice of the selective antagonist of the non-NMDA-type receptor antagonist 6-cyano-7nitroquinoxaline-2,3-dione (CNQX) and of the NMDA-type receptor 2-amino-5-phosphonopentanoic acid (D-AP5) resulted in a drastic reduction of the endogenous NF- $\kappa \mathrm{B}-$ binding activity. In the adult mouse cerebellum NF- $\kappa \mathrm{B}$ was not inducible by intraperitoneal injection of glutamate receptor agonists, suggesting a time window in which $\mathrm{NF}-\kappa \mathrm{B}$ could be activated by these stimuli.

\section{MATERIALS AND METHODS}

Animals and drug treatments. Mice were kept under a $12 \mathrm{hr}$ light/dark cycle and given food and water ad libitum. Whole brains were removed for dissections, and cerebellum, neocortex, and hippocampus were immediately frozen in liquid nitrogen. All samples were stored at $-80^{\circ} \mathrm{C}$ until use. Kainic acid (adult mice, $8 \mathrm{mg} / \mathrm{kg}$; neonatal, $1 \mathrm{mg} / \mathrm{kg}$ ), transACPD (3 mg/kg), NMDA (adult mice, $8 \mathrm{mg} / \mathrm{kg}$; neonatal, $2 \mathrm{mg} / \mathrm{kg}$ ), D-AP5 $(10 \mathrm{mg} / \mathrm{kg})$, and CNQX $(1 \mathrm{mg} / \mathrm{kg})$ were injected intraperitoneally. All drugs were from Research Biochemical International.

Nuclear extracts and EMSAs. Nuclear extracts were prepared essentially according to the methods of Dignam et al. (1983); briefly, tissue samples were homogenized in $100 \mu \mathrm{l}$ of buffer A (in mM: 10 HEPES, $\mathrm{pH}$ 7.9 at $4^{\circ} \mathrm{C}, 1.5 \mathrm{MgCl}_{2}, 10 \mathrm{KCl}$, and $0.5 \mathrm{DTT}$ ) and left for $10 \mathrm{~min}$ on ice; after addition of $5 \mu \mathrm{l}$ of $10 \%$ Triton X-100 the homogenates were vortexed for $30 \mathrm{sec}$ and then centrifuged for $1 \mathrm{~min}$ at 13,000 rpm; the nuclear pellet was dissolved in $30 \mu \mathrm{l}$ of buffer C [ 20 mM HEPES, $\mathrm{pH} 7.9$, $25 \%$ (v/v) glycerol, $0.42 \mathrm{M} \mathrm{NaCl}, 1.5 \mathrm{~mm} \mathrm{MgCl}_{2}, 0.2 \mathrm{~mm}$ EDTA, $2 \mathrm{~mm}$ phenylmethylsulfonyl fluoride (PMSF), and $2 \mathrm{~mm} \mathrm{DTT]}$ and left for 30 min at $4^{\circ} \mathrm{C}$ with constant agitation; after centrifugation as above, the nuclear extracts were aliquoted, frozen in liquid nitrogen, and stored at $-80^{\circ} \mathrm{C}$ until use. Oligonucleotides encompassing the double human immunodeficiency virus 1 (HIV-1) NF- $\kappa \mathrm{B}$ site (Nabel and Baltimore, 1987), the human leukocyte antigen (HLA) site (Chang et al., 1994), and the AP-1 site (Guerrini et al., 1996) were used as probes and 5'-labeled with $\gamma_{-}^{-32} \mathrm{P}$ and T4 polynucleotide kinase. Binding reactions with $10 \mu \mathrm{g}$ of nuclear extracts were performed in a $20 \mu \mathrm{l}$ volume containing $20,000 \mathrm{cpm}$ of probe, $2 \mu \mathrm{g}$ of poly[d(I-C)], $10 \mu \mathrm{l}$ of TK100 buffer ( $25 \mathrm{mM}$ HEPES, $\mathrm{pH}$ 7.9, $20 \%$ glycerol, $1 \mathrm{~mm}$ EDTA, $100 \mathrm{~mm} \mathrm{KCl,} 2 \mathrm{~mm} \mathrm{MgCl}_{2}, 2 \mathrm{~mm}$ dithiothreitol, and $2 \mathrm{~mm}$ PMSF) and competitor as indicated. Nuclear extracts were incubated with the poly[d(I-C)] on ice for $10 \mathrm{~min}$, and then the buffer and probe were added. Incubation was continued for $20 \mathrm{~min}$ at room temperature, after which reaction mixtures were loaded on a $5 \%$ nondenaturing polyacrylamide gel in $0.25 \times$ Tris borate/EDTA $[1 \times=($ in mM) 89 Tris base, 89 boric acid, and 2 EDTA, pH 7.2]. Gels were dried and exposed to x-ray film. When antibodies were used in EMSA, nuclear extracts were incubated with the different antibodies for $30 \mathrm{~min}$ at $4{ }^{\circ} \mathrm{C}$ before the addition of the poly[d(I-C)].

Sera raised against RelA (serum 1226), NFKB1 (serum 1263), NFKB2 (serum 1495), c-Rel (serum 1266), RelB (serum 1318), and C-terminal NFKB1 (serum 1140) were kindly provided by Dr. N. Rice (National Cancer Institute, Frederick, MD).

RNase protection assays. Total RNA was extracted from brain tissue samples by the Trizol reagent (Gibco-BRL) according to the instructions of the manufacturer. For RNase protection assays a transgene-specific $\beta$-globin antisense probe of 230 bases overlapping the start site of transcription was generated by in vitro transcription with $\left[{ }^{32} \mathrm{P}\right]$ uridine triphosphate using T7 RNA polymerase. Labeled probe was incubated with $30 \mu \mathrm{g}$ of total RNA overnight at $55^{\circ} \mathrm{C}$, digested with RNases, and analyzed by denaturing polyacrylamide gel electrophoresis as described (Wirth et al., 1991). For positive control, RNA was extracted from the S194 mouse plasmacytoma cell line transiently transfected with the $3 \times \kappa B$ globin plasmid (Wirth and Baltimore, 1988).

\section{RESULTS}

\section{$\mathrm{NF}-\kappa \mathrm{B}$ activation is restricted to the developing cerebellum}

To verify the activation state of NF- $\kappa$ B and AP- 1 during brain development, we prepared nuclear extracts from cerebellum, neocortex, and hippocampus from neonatal mice and used them in EMSAs using as probe an oligonucleotide encompassing the double NF- $\kappa \mathrm{B}$ site of the HIV long terminal repeat or the AP-1 site of the urokinase promoter. Nuclear extracts derived from the neocortex and hippocampus did not show any NF- $\kappa$ B DNAbinding activity at all stages examined. On the other hand, in nuclear extracts derived from the cerebellum, NF- $\kappa$ B DNAbinding activity was not present at 5 and $6 \mathrm{PN}$ whereas a specific $\mathrm{NF}-\kappa \mathrm{B}$-binding activity was visible in extracts derived from 7 and 9 PN (Fig. 1 $A$ ).

When the same extracts were used to analyze the expression of the transcription factor AP-1, which has been extensively studied in the mouse brain (Vendrell et al., 1993), the following results 


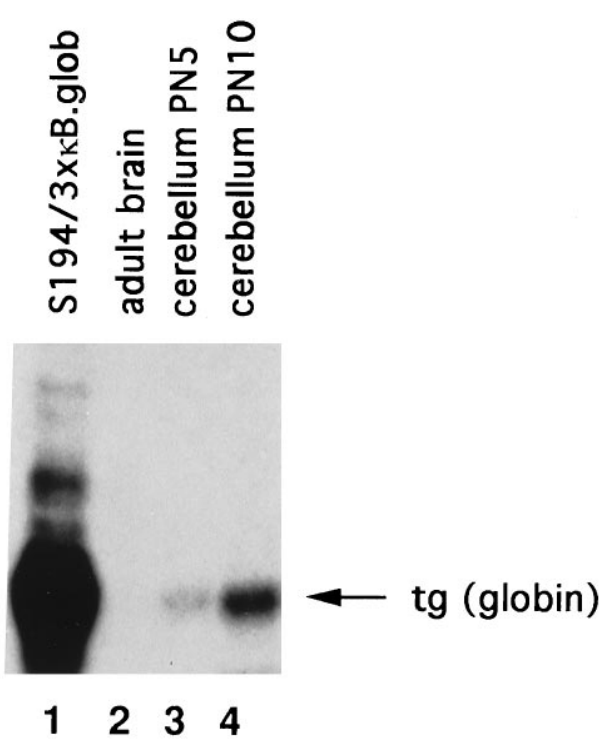

Figure 2. A $\kappa \mathrm{B}$-transgene is activated during cerebellum development. Total RNAs $(30 \mu \mathrm{g})$ from adult brain, 5 and $10 \mathrm{PN}$ cerebella from mice carrying a $3 \times \kappa \mathrm{B}$-human $\beta$-globin (B.glob) transgene, were used in RNase protection experiments with a human $\beta$-globin probe. Transgene expression is not detected in the adult brain (lane 2), is slightly detectable in 5 PN cerebellum (lane 3), and is increased in $10 \mathrm{PN}$ cerebellum (lane 4). Lane 1, RNA extracted from the S194 mouse plasmacytoma cell line transiently transfected with the $3 \times \kappa \mathrm{B} \beta$-globin plasmid (positive control).

were obtained (Fig. $1 B$ ). In the neocortex, AP-1-binding activity was not present at $5 \mathrm{PN}$ but was detectable from $6 \mathrm{PN}$ on. AP-1-binding activity was present in the hippocampus at $5 \mathrm{PN}$ and increased thereafter. No AP-1-binding activity was detected in the extracts of 5-9 PN cerebella. From these data we concluded that $\mathrm{NF}-\kappa \mathrm{B}$ is developmentally activated specifically in the cerebellum, and that the domains of expression of the two transcription factors examined are not overlapping.

\section{A $\kappa$ B-globin transgene is activated during cerebellar development}

To verify whether NF- $\kappa \mathrm{B}$ nuclear translocation in the developing cerebellum correlated with transcriptional activation of a $\kappa \mathrm{B}$ dependent gene, we used mice carrying a transgene containing three copies of the $\kappa \mathrm{B}$ motif from the $\operatorname{Ig} \kappa$ enhancer inserted upstream of the $\beta$-globin TATA box, promoter, and the $\beta$-globin reporter gene. These mice express the transgene in response to $\mathrm{NF}-\kappa \mathrm{B}$ activation in the spleen and thymus (Lernbercher et al., 1993). As shown in Figure 2, RNase protection experiments on whole adult mouse brain RNA did not reveal any transgene expression (lane 2), which agrees with the lack of active nuclear $\mathrm{NF}-\kappa \mathrm{B}$ in the adult mouse brain (Guerrini et al., 1995). When RNA was extracted from 5 PN cerebellum (Fig. 2, lane 3) a weak transgene expression was visible. By $10 \mathrm{PN}$, transgene expression strongly increased (Fig. 2, lane 4).

These data show that in vivo activation of $\mathrm{NF}-\kappa \mathrm{B}$ during cerebellum development correlates with transcription of $\kappa \mathrm{B}$ dependent genes and therefore strongly suggest a functional role of developmentally regulated NF- $\kappa \mathrm{B}$ activation in cerebellum.

\section{$\mathrm{NF}-\kappa \mathrm{B}$ activation in cerebellum is counteracted by glutamate receptor antagonists}

To verify whether developmental activation of NF- $\kappa$ B at 9 PN was attributable, as in cultured cells, to glutamate receptor stimulation in vivo, we intraperitoneally injected $9 \mathrm{PN}$ mice with the

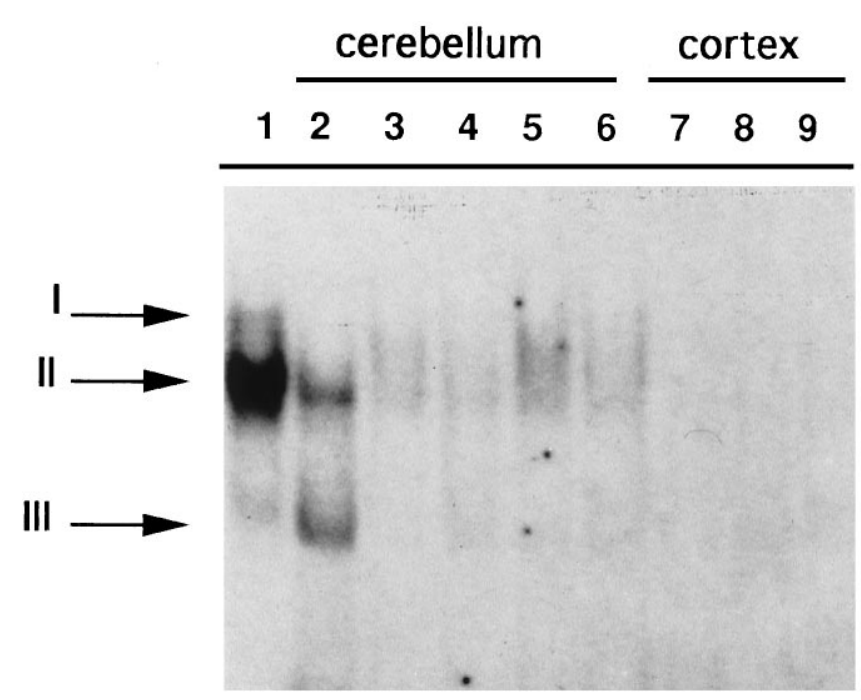

Figure 3. NF- $\kappa \mathrm{B}$ activation in $9 \mathrm{PN}$ mice can be reversed by intraperitoneal injection of glutamate receptor antagonists. EMSA experiments with an HLA $\kappa$ B oligonucleotide as probe from 9 PN untreated mice extracts retarded two bands in the cerebellum (lane 2, II, III) but not in the neocortex (lane 7). Intraperitoneal injection with CNQX (10 and 20 $\min$ ) reverts NF- $\kappa$ B activation (lanes 3, 4); D-AP5 (10 and $20 \mathrm{~min}$ ) had similar effects (lanes 5, 6). Treatment of mice for $20 \mathrm{~min}$ with CNQX (lane 8) or D-AP5 (lane 9) had no effect in the neocortex. In lane 1, HeLa-activated cytoplasmic extracts retarded two complexes: $I$ and $I I$, which have been shown previously to be RelA-c-Rel and RelA-NFKB1 heterodimers, respectively (Hansen et al., 1992).

non-NMDA receptor antagonist CNQX (Turski et al., 1990) and with the NMDA receptor antagonist D-AP5 (Croucher et al., 1982; Meldrum, 1992). As shown in Figure 3, in mouse cerebellar nuclear extracts prepared 10 or 20 min after CNQX injection (lanes 3 and 4 ) the levels of NF- $\kappa \mathrm{B}$-binding activity were significantly reduced compared with untreated animals (lane 2). Similar results were obtained with intraperitoneal injection of D-AP5 (Fig. 3, lanes 5 and 6 ). The injection of CNQX (Fig. 3, lane 8) and D-AP5 (Fig. 3, lane 9) did not activate NF- $\kappa$ B-binding activity in the neocortex, nor did they inhibit AP-1-binding activity in the neocortex (data not shown). These data indicate that the observed in vivo activation of NF- $\kappa \mathrm{B}$ may be attributable to endogenous glutamate receptor stimulation, during the physiological maturation of the cerebellum after $7 \mathrm{PN}$, and that this effect is not shared with other factors binding the AP-1 site.

\section{NF- $\kappa \mathrm{B}$ is inducible by neurotransmitters in the developing cerebellum}

If the constitutive activity of $9 \mathrm{PN}$ cerebellar NF- $\kappa \mathrm{B}$ really depends on endogenous glutamate receptor stimulation, it might be possible to activate $\mathrm{NF}-\kappa \mathrm{B}$ at earlier times by injecting glutamate receptor agonists. To achieve this goal, we prepared nuclear extracts from 5 PN mice after intraperitoneal injection of different ionotropic glutamate receptor agonists. The glutamate receptors known to be expressed in mouse cerebellum at this age are mainly of the NMDA and metabotropic subtypes, with the nonNMDA receptor subtype being expressed at very low levels (D’Angelo et al., 1993; Farrant et al., 1994). As shown in Figure 4, control intraperitoneal injection of saline solution (PBS) to 5 $\mathrm{PN}$ mice did not activate NF- $\mathrm{B}$ (lane 1) and had no effect on mice behavior. Kainic acid, a selective activator of the nonNMDA subtype of glutamate receptors, caused a convulsive status epilecticus. Cerebellar nuclear extracts of these mice pre- 


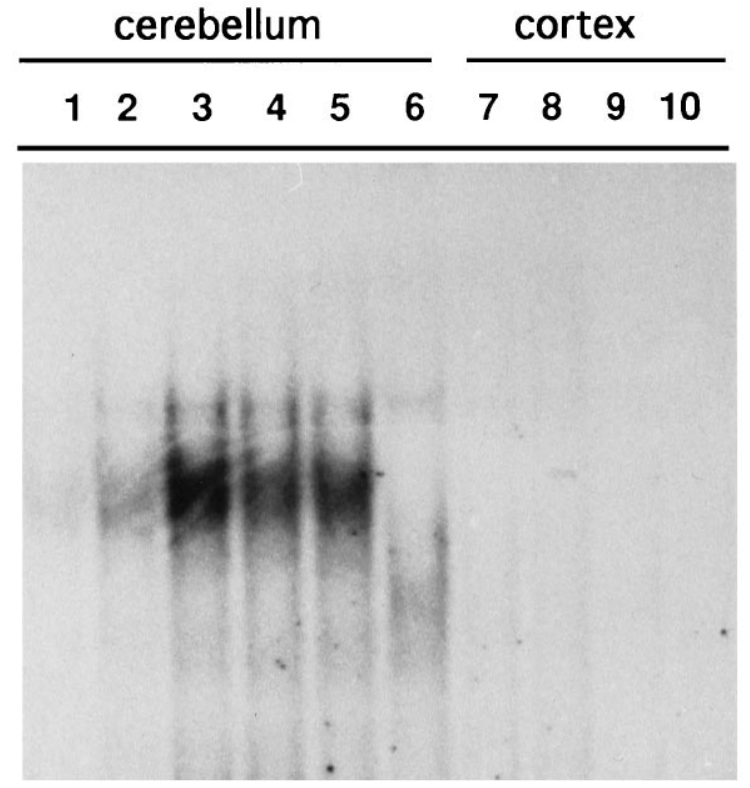

Figure 4. NF- $\kappa \mathrm{B}$ is induced in $5 \mathrm{PN}$ cerebellum by intraperitoneal injection of NMDA and trans-ACPD. Nuclear extracts were prepared from $5 \mathrm{PN}$ mice after intraperitoneal injection with glutamate receptor agonists and used in EMSA with an HIV- $\kappa \mathrm{B}$ oligonucleotide as probe. Lane 1, Cerebellum extracts of PBS-injected mice; $15 \mathrm{~min}$ of kainic acid slightly induces NF- $\kappa \mathrm{B}$-binding activity (lane 2); $30 \mathrm{~min}$ of NMDA intraperitoneally results in a strong induction (lane 3), as also observed with 30 and $60 \mathrm{~min}$ treatments with trans-ACPD (lanes 4, 5). Lane 6, Specific competition of the cerebellum extracts from NMDA-treated animals by unlabeled $\kappa \mathrm{B}$ oligonucleotide. In neocortex extracts, NF- $\kappa \mathrm{B}$ is not detected after injection of PBS (lane 7), kainic acid (lane 8, $15 \mathrm{~min}$ ) NMDA (lane 9, $30 \mathrm{~min}$ ), and trans-ACPD (lane 10, $60 \mathrm{~min}$ ).

pared 15 min after the injection contained modest NF- $\kappa \mathrm{B}$ activity (Fig. 4, lane 2), in agreement with the low levels of expression of the cerebellar non-NMDA receptor subtype at this age (D'Angelo et al., 1993). The same results were obtained with longer (up to $40 \mathrm{~min}$ ) kainic acid treatments (not shown). On the other hand, intraperitoneal injection of NMDA for 30 or $60 \mathrm{~min}$ rendered the mice hypotonic. This coincided with $\mathrm{NF}-\kappa \mathrm{B}$ activation (Fig. 4, lane 3; $30 \mathrm{~min}$ ). Injection of trans-ACPD, which activates the metabotropic subtype of glutamate receptors, resulted in massive myoclonic and tonic seizures and, again, NF- $\kappa \mathrm{B}$ activation at 30 and $60 \mathrm{~min}$ (Fig. 4, lanes 4 and 5, respectively). Kainic acid, NMDA, and trans-ACPD treatments did not result in NF- $\kappa \mathrm{B}$ activation in the neocortex (Fig. 4, lanes $8-10$ ). When we used the same extracts with the AP-1 oligonucleotide, no AP-1-binding activity was detected in the cerebellum or neocortex of either untreated or treated animals (data not shown). These data indicate that there is a tissue-restricted activation of NF- $\kappa \mathrm{B}$ by glutamate receptor activation.

\section{Immunological characterization of developmentally activated NF- $\mathrm{B}$}

We next examined the subunit composition of developmentally activated NF- $\kappa \mathrm{B}$ complexes. Gel mobility shift experiments were performed with nuclear extracts from $8 \mathrm{PN}$ mice pups incubated with the HLA gene $\kappa \mathrm{B}$ site. Figure 5, lane 1, shows that two complexes (I and II) could be detected in cerebellar nuclear extracts of $8 \mathrm{PN}$ animals. To identify the proteins responsible for the formation of these complexes, we used antisera directed

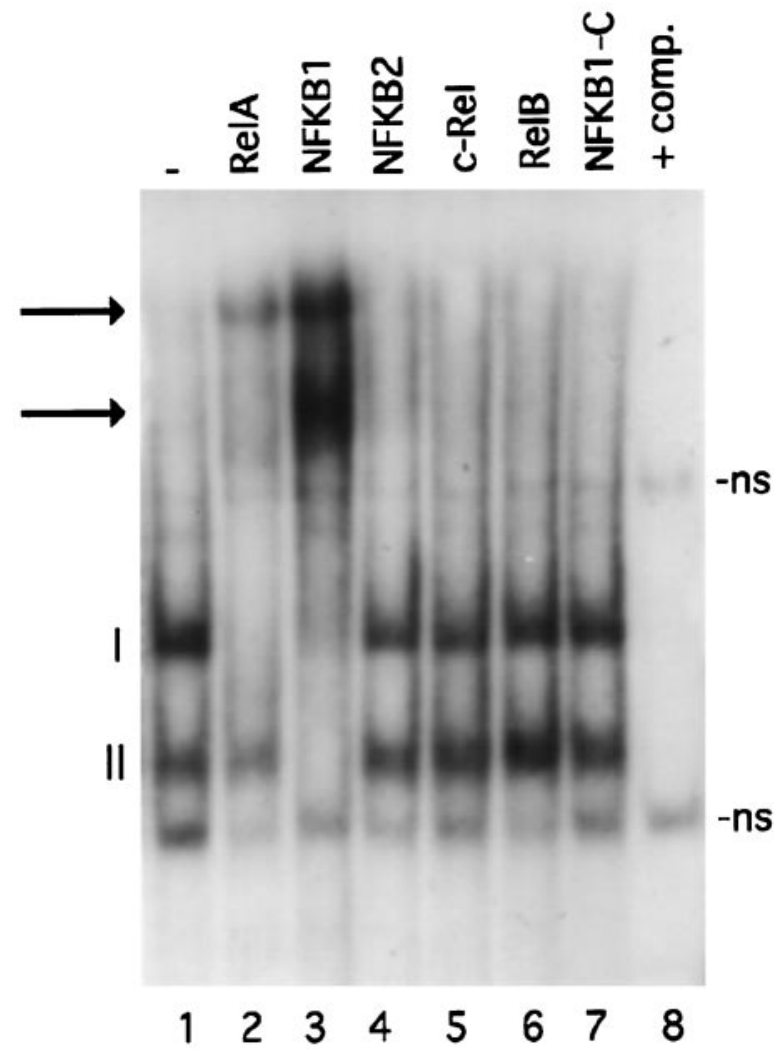

Figure 5. Immunological characterization of NF- $\kappa \mathrm{B}$ subunits. Nuclear extracts prepared from 8 PN cerebella incubated with a labeled oligonucleotide corresponding to the $\kappa \mathrm{B}$ site of an HLA promoter gene retard two bands (lane 1, I, II). The addition of specific antisera against different members of the NF- $\kappa \mathrm{B}$ family is indicated at the top. The arrows show the supershifted bands. Lane 8, Competition (+comp.) with 100× excess unlabeled oligonucleotide. $n s$, Nonspecific bands.

against each of the five members of the NF- $\kappa$ B family. Serum against RelA inhibited the formation of complex I and had no effect on complex II (Fig. 5, lane 2). The anti-NFKB1 serum inhibited both complexes (Fig. 5, lane 3). The NFKB2, c-Rel, and RelB sera (Fig. 5, lanes 4-6) did not have any effect. As a control we used an antiserum directed against the $\mathrm{C}$-terminal of the NFKB1 p105 precursor (Fig. 5, lane 7), which is not retained in the active protein p50 and had no effect. DNA-binding specificity was demonstrated by addition of $100 \times$ excess unlabeled competitor (Fig. 5, lane 8). The same results were obtained with NMDA and trans-ACPD nuclear extracts derived from 5 PN mice (not shown). From these data we conclude that complex I is composed of RelA-NFKB1 heterodimers and that complex II contains NFKB1 homodimers.

\section{NF- $\mathrm{B}$ is not inducible by glutamate agonists in the adult cerebellum}

To verify whether activation of $\mathrm{NF}-\kappa \mathrm{B}$ in response to glutamate receptor activation was restricted to the developing cerebellum, we intraperitoneally injected glutamate receptor agonists in 12-week-old mice. At this age NF- $\kappa \mathrm{B}$ subunits are expressed but retained in the cell cytoplasm (Guerrini et al., 1995). Nuclear extracts derived from cerebellum, neocortex, and hippocampus of mice treated for $1 \mathrm{hr}$ with kainic acid, which rendered the mice ataxic, did not increase $\mathrm{NF}-\kappa \mathrm{B}-$ binding activity (Fig. $6 A$, lanes $4-6$ ). Modest NF- $\kappa$ B-binding 
A

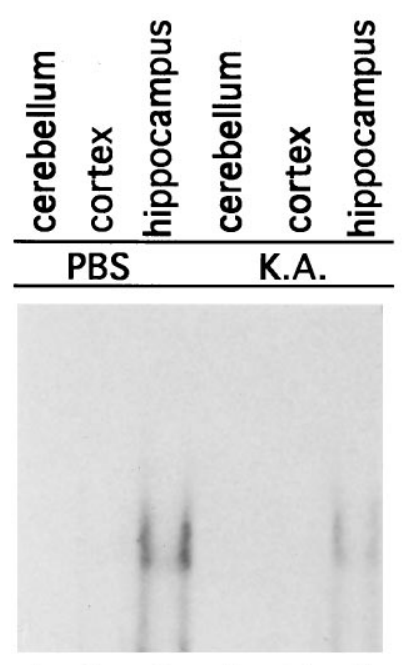

$\begin{array}{llllll}1 & 2 & 3 & 4 & 5 & 6\end{array}$
B
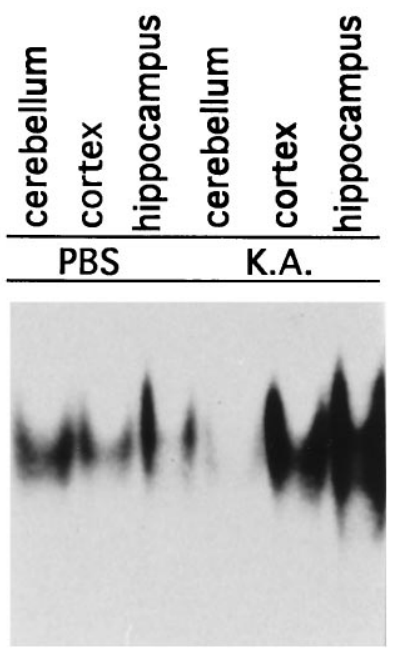

$\begin{array}{llllll}1 & 2 & 3 & 4 & 5 & 6\end{array}$
Figure 6. NF- $\kappa \mathrm{B}$ is not inducible by glutamate receptor agonists in the adult mouse cerebellum. Analysis of NF- $\kappa$ B- and AP-1-binding activities of extracts from 12-week-old mice intraperitoneally injected with kainic acid. $A$, Nuclear extracts from cerebellum, neocortex, and hippocampus of PBS-injected animals (lanes 1-3); $1 \mathrm{hr}$ after intraperitoneal injection of kainic acid, no activation of NF- $\kappa \mathrm{B}$ in the cerebellum, neocortex, and hippocampus is evident (lanes 4-6). B. AP-1 is present in cerebellum, neocortex, and hippocampus of PBS-treated animals (lanes 1-3) and is induced by kainic acid in neocortex and hippocampus (lanes 5, 6) but not in cerebellum (lane 4).

activity, in agreement with recently published data (SchmidtUllrich et al., 1996), was visible in hippocampus protein extracts (Fig. 6A, lane 3 ) but was not induced by this treatment (Fig. 6A, lane 6). The transcription factor AP-1, known to be induced in several brain regions by this treatment (Vendrell et al., 1993), was indeed activated in the neocortex and hippocampus (Fig. $6 B$, lanes 5 and 6 ). Surprisingly, in the cerebellum we observed a reduction of AP-1-binding activity (Fig. 6B, lane 4 ). These data were similar to those recently reported for the rat brain (Rong and Baudry, 1996), in which kainic acid injection failed to activate NF- $\kappa$ B and AP-1 in the cerebellum, with actually a slight reduction of AP-1-binding activity in the cerebellum after kainic acid injection. Similar results were obtained with NMDA-treated animals (data not shown). These data show that NF- $\kappa \mathrm{B}$ activity is susceptible to neurotransmitter activation only during cerebellum development.

\section{DISCUSSION}

Trans-synaptic regulation of gene expression is critical for neuronal development and for long-term adaptive changes in the mature nervous system. In the cerebellar cortex, granule cells migrate from the external germinal layer where they are generated and cross the molecular layer to reach their final destination in the internal granular layer. The rate of granule cell movements depends on both extracellular $\mathrm{Ca}^{2+}$ concentration and $\mathrm{Ca}^{2+}$ influx through $\mathrm{N}$-type $\mathrm{Ca}^{2+}$ channels (Komuro and Rakic, 1992, 1993). Activation of specific transcription factors on $\mathrm{Ca}^{2+}$ influx may play a crucial role in regulating granule cell maturation and migration.

In this paper we show that $\mathrm{NF}-\kappa \mathrm{B}$ is present in an inducible form in cerebella of mice pups up to $6 \mathrm{PN}$. At this stage, no constitutive NF- $\kappa$ B was observed, but intraperitoneal injections of glutamate receptor agonists induced its nuclear translocation. We think that NF- $\kappa \mathrm{B}$ activation after intraperitoneal injection of glutamate receptor agonists does not reflect downstream events of generalized CNS damage, because the drug having the greatest neurotoxic and traumatic effect results in the weakest $\mathrm{NF}-\kappa \mathrm{B}$ response. After intraperitoneal injection of kainic acid, mice occasionally died as a consequence of convulsive seizures (epileptic status). However, the tissue extracted from these animals showed poor activation of NF- $\kappa \mathrm{B}$, as did tissue extracted from mice that were not killed by the injection (Fig. 4). On the other hand, a good NF- $\kappa$ B response was observed in the animals injected with NMDA and transACPD (Fig. 4), in which severe seizures or casualties were never observed.

In nuclear extracts from cerebella of 7-9 PN mice, NF- $\kappa \mathrm{B}$ is constitutively activated. The fact that the activation of NF- $\kappa \mathrm{B}$ in $9 \mathrm{PN}$ mice can be inhibited by treatment with ionotropic glutamate receptor antagonists (CNQX and D-AP5) suggests that this activation depends on an autocrine-paracrine loop of glutamate receptor activation, possibly through glutamate itself synthesized and released by neurons and/or astrocytes (Gallo et al., 1982). In this case, an astrocyte- and neuronsignaling pathway, regulating NF- $\kappa \mathrm{B}$ activity, could be operative in the cerebellum. Indeed, in vitro-cultured astrocytes synthesize glutamate, which can transfer signals to neurons via glutamate and glutamate receptors (Parpura et al., 1994). On the other hand, in vivo synaptic source of glutamatergic input to granule cells has been demonstrated to be mediated by mossy fibers arising from the deep cerebellar nuclei and brainstem (Eccles et al., 1967).

One possible function of NF- $\kappa$ B activation might be the control of cell migration, possibly by regulating the expression of adhesion molecules or their receptors through NMDA receptors (Komuro and Rakic, 1992, 1993). Migration of cells is a complex phenomenon that requires an extremely tight program of adhesion-promoting, proteolytic, and motogenic steps. A role of NF- $\kappa \mathrm{B}$ in this type of processes can be observed in cell culture systems, in which the block of RelA synthesis by antisense technology resulted in decreased adhesion of the cells (Narayan et al., 1993). Moreover, NF- $\kappa$ B induces synthesis of several motogenic factors and proteolitic enzymes important in cell migration (Guerrini et al., 1996). Another possibility is that NF- $\kappa B$ is involved in the regulation of synaptogenesis by elimination of exuberant collateral synapses. This process has in fact been shown to occur during cerebellum development and to be regulated by $\mathrm{Ca}^{2+}$ influx through NMDA receptors. In the first postnatal week in the rat, a single Purkinje cell is innervated by several climbing fibers; a massive elimination of most synapses through the withdrawal of axonal collaterals then occurs. As a consequence of this process, the innervation of each Purkinje cell by only one climbing fiber, typical of the adult stage, is attained on postnatal day 15. In vivo administration of the glutamate receptor antagonist D-AP5 has been shown to block this process (Rabacchi et al., 1992a,b).

Nothing is known about the function of NF- $\kappa \mathrm{B}$ in the CNS. Data from the targeted disruption of NFKB1 (Sha et al., 1995), c-Rel (Kontgen et al., 1995), RelB (Burkly et al., 1995) and $\mathrm{I} \kappa \mathrm{B} \alpha$ 
(Beg et al., 1995a) did not reveal any major alteration of the CNS. RelA knock-out mice, on the other hand, die at approximately embryonic day 16 of massive liver apoptosis, too early to detect any defect in the CNS (Beg et al., 1995b). On the other hand, because RelA has been identified in all brain regions examined (Guerrini et al., 1995), and it is found in all activated dimers in the adult mouse brain (Schmidt-Ullrich et al., 1996), in the various knock-out animals other members of the $\mathrm{NF}-\kappa \mathrm{B} / \mathrm{Rel}$ family might substitute for one another, producing no major phenotypic alteration.

The presence in 9 PN cerebellar extracts of dimers with trans-activating potential (RelA-NFKB1 heterodimers) and dimers with no trans-activating capacity (NFKB1 homodimers) delineates a complex system for NF- $\kappa$ B-regulated gene expression. Different genes containing NF- $\kappa$ B sites in their regulatory regions may be activated or repressed during cerebellum development depending on the affinity of each particular $\kappa \mathrm{B}$ site for the different dimers. Differential affinity of the RelA-NFKB1 and RelA-c-Rel heterodimers or the NFKB1 and RelA homodimers has in fact been observed and results in differential transcriptional effects of the various combinations (Hansen et al., 1994a,b). Differential regulation of gene expression by one of the NF- $\kappa \mathrm{B}$ subunits has been observed in NFKB1 knock-out mice, in which interleukin-6 (IL-6) gene expression was reduced and interferon- $\beta$ (IFN- $\beta$ ) was augmented, suggesting that IL- 6 needs NFKB1 for its expression, whereas IFN- $\beta$ is repressed by the same factor in wild-type animals (Sha et al., 1995).

The lack of NF- $\kappa \mathrm{B}$ activation on glutamatergic stimuli in adult mice suggests a fundamental difference in the cascade of intracellular events responding to synaptic glutamate receptor activation between the developing and mature cerebella. We suggest that the kinases involved in the degradation of the $\mathrm{I} \kappa \mathrm{B}$ molecules, which maintain NF- $\kappa \mathrm{B}$ in the cell cytoplasm, must respond differently to the same stimuli between the developing and adult cerebella. Silencing in the adult cerebellum of the intracellular steps leading to $\mathrm{I} \kappa \mathrm{B}$ degradation could actually be a "secondary effect" of NF- $\kappa$ B activation.

Trans-synaptic regulation of gene expression is critical for neuronal development. Neurotransmitters released from the presynaptic cells regulate gene expression in postsynaptic neurons by binding to and activating specific postsynaptic receptors. From our data, the action of NF- $\kappa \mathrm{B}$ seems to be regulated in a temporally and spatially restricted fashion and may possibly lead to regulation of specific genes involved in the formation of this brain region.

In conclusion, the existence of a well known primary transcription factor and its induction in response to glutamate receptor activation during cerebellum development represent a novel pathway for regulating gene expression during CNS development.

\section{REFERENCES}

Altman J (1982) The cerebellum: new vistas. Berlin: Springer.

Bang AG, Goulding MD (1996) Regulation of vertebrate neural cell fate by transcription factors. Curr Opin Neurobiol 6:25-32.

Beg AA, Sha WC, Bronson RT, Baltimore D (1995a) Constitutive NF- $\kappa$ B activation, enhanced granulopoiesis, and neonatal lethality in I $\kappa$ b- $\alpha$ deficient mice. Genes Dev 9:2736-2746.

Beg AA, Sha WC, Bronson RT, Ghosg S, Baltimore D (1995b) Embryonic lethality and liver degeneration in mice lacking the RelA component of NF- $\kappa$ B. Nature 376:167-170.

Burkly L, Hession C, Ogata L, Reilly C, Marconi LA, Olson D, Tizard R, Cate R, Lo D (1995) Expression of RelB is required for the development of thymic medulla and dendritic cells. Nature 373:531-536.

Chang CC, Zhang J, Lombardi L, Neri A, Dalla-Favera R (1994) Mechanism of expression and role in transcriptional control of the protooncogene NFKB-2/LYT-10. Oncogene 9:923-933.

Croucher MJ, Collins JF, Meldrum BS (1982) Anticonvulsant action of excitatory amino acid antagonist. Science 216:899-901.

D'Angelo E, Rossi P, Taglietti V (1993) Different proportion of $N$-methyl-D-aspartate and non- $N$-methyl-D-aspartate receptor currents in rat cerebellar granule cells. Neuroscience 53:121-130.

Dignam JD, Lebovitz RM, Roeder RG (1983) Accurate transcription initiation by RNA polymerase II in a soluble extract from isolated mammalian nuclei. Nucleic Acids Res 11:1475-1488.

Eccles JC, Ito M, Szentagothai J (1967) The cerebellum as a neuronal machine. Berlin: Springer.

Farrant M, Feldmeyer D, Takahashi T, Cull-Candy SG (1994) NMDAreceptor channel diversity in the developing cerebellum. Nature 368:335-338.

Gallo V, Ciotti MT, Coletti A, Aloisi F, Levi G (1982) Selective release of glutamate from cerebellar granule cells differentiating in culture. Proc Natl Acad Sci USA 79:7919-7923.

Grilli MG, Chiu JS, Lenardo MJ (1993) NF- $\kappa$ B and Rel: participants in a multiform transcriptional regulatory system. Int Rev Cytol 143:1-62.

Guerrini L, Blasi F, Denis-Donini S (1995) Synaptic activation of NF- $\kappa$ B by glutamate in cerebellar granule neurons in vitro. Proc Natl Acad Sci USA 92:9077-9081.

Guerrini L, Casalino L, Corti A, Blasi F (1996) NF- $\kappa$ B mediated regulation of urokinase gene expression by PMA and TNF- $\alpha$ in human A549 cells. FEBS Lett 393:69-73.

Hansen SK, Nerlov C, Zabel U, Verde P, Johnsen M, Baeuerle PA, Blasi $F$ (1992) A novel complex between the p65 subunit of NF- $\kappa$ B and c-Rel binds to a DNA element involved in the phorbol ester induction of the human urokinase gene. EMBO J 11:205-213.

Hansen SK, Baeuerle PA, Blasi F (1994a) Purification, reconstitution, and IkB association of the c-Rel-p65 (RelA) complex, a strong activator of transcription. Mol Cell Biol 14:2593-2603.

Hansen SK, Guerrini L, Blasi F (1994b) Differential DNA sequence specificity and regulation of HIV-1 enhancer and cellular promoters by the c-Rel-RelA transcription factor. J Biol Chem 269:22230-22237.

Hatten ME, Heintz N (1995) Mechanism of neural patterning and specification in the developing cerebellum. Annu Rev Neurosci 18:385-408.

Komuro H, Rakic P (1992) Selective role of N-type calcium channels in neuronal migration. Science 257:806-808.

Komuro H, Rakic P (1993) Modulation of neuronal migration by NMDA receptors. Science 260:95-97.

Kontgen F, Grumont RJ, Strasser A, Metcalf D, Li R, Tarlinton D, Gerondakis S (1995) Mice lacking the c-Rel proto-oncogene exhibit defects in lymphocyte proliferation, humoral immunity, and interleukin-2 expression. Genes Dev 9:1965-1977.

Kuhar SG, Feng L, Vidan S, Ross ME, Hatten ME, Heintz N (1993) Changing patterns of gene expression defines 4 stages of cerebellar granule neuron differentiation. Development 117:97-104.

Lernbercher T, Muller U, Wirth T (1993) Distinct NF- $\kappa$ B/Rel transcription factors are responsible for tissue specific and inducible gene activation. Nature 365:767-770.

Meldrum BS (1992) Excitatory amino acid in epilepsy and potential novel therapies. Epilepsy Res 12:189-196.

Miyamoto S, Chiao P, Verma I (1994) Enhanced I $\kappa \mathrm{B} \alpha$ degradation is responsible for constitutive $\mathrm{NF}-\kappa \mathrm{B}$ activity in mature murine B-cell line. Mol Cell Biol 14:3276-3282.

Nabel G, Baltimore D (1987) An inducible transcription factor activates expression of human immunodeficiency virus in $\mathrm{T}$ cells. Nature 326:711-713.

Narayan R, Higgins KA, Perez JR, Coleman TA, Rosen CA (1993) Evidence for differential functions of the p50 and p65 subunits of NF-kB with a cell adhesion model. Mol Cell Biol 13:3802-3810.

Parpura V, Basarsky TA, Liu F, Jeftinija K, Jeftinija S, Haydon PG (1994) Glutamate-mediated astrocyte-neuron signalling. Nature 369:744-747.

Rabacchi SA, Bailly Y, Delhaye-Bouchaud N, Mariani J (1992a) Involvement of the $N$-methyl-D-aspartate (NMDA) receptor in synapse elimination during cerebellar development. Science 256:1823-1825.

Rabacchi SA, Bailly Y, Delhaye-Bouchaud N, Herrup K, Mariani J (1992b) Role of the target in synapse elimination: studies in cerebel- 
lum of developing lurcher mutants and adult chimeric mice. J Neurosci 12:4712-4720.

Ramon y Cayal (1889) Sobra las fibras nerviosas de la capa granulosa del cerebelo. Rev Trim Histol Norm Pathol 3,4:5.

Rong Y, Baudry M (1996) Seizure activity results in a rapid induction of nuclear factor-kB in adult but not juvenile rat limbic structure. J Neurochem 67:662-668.

Schmidt-Ullrich R, Memet S, Liliebaum A, Feuillard J, Raphael M, Israel A (1996) NF- $\kappa$ B activity in transgenic mice: developmental regulation and tissue specificity. Development 122:2117-2128.

Sha W, Liou HC, Tuomanen EI, Baltimore D (1995) Targeted disruption of the p50 subunit of NF- $\mathrm{BB}$ leads to multifocal defects in immune responses. Cell 80:321-330.

Turski L, Bressler K, Klockgether T, Stephens DN (1990) Differential effect of the excitatory amino acid antagonist, 6-cyano-7- nitroquinoxaline-2,3-dione (CNQX) and 3-((+)-2-carboxypiperazin-4yl)-propyl-1-phosphonic acid (CPP), on spinal reflex activity in mice. Neurosci Lett 113:66-71.

Vendrell M, Curran T, Morgan JI (1993) Glutamate, immediate-early genes, and cell death in the nervous system. Ann NY Acad Sci 679:132-141.

Verma I, Stevenson J, Schwarz E, Antwerp D, Miyamoto S (1995) $\mathrm{Rel} / \mathrm{NF}-\kappa \mathrm{B} / \mathrm{I} \kappa \mathrm{B}$ family: intimate tales of association and dissociation. Genes Dev 9:2723-2735.

Wirth T, Baltimore D (1988) Nuclear factor NF kappa B can interact functionally with its cognate binding site to provide lymphoid-specific promoter function. EMBO J 7:3109-3113.

Wirth T, Priess A, Annweiler A, Zwilling S, Oeler B (1991) Multiple OCT2 isoform are generated by alternative splicing. Nucleic Acids Res 19:43-51. 